\title{
Optimalisasi Penggunaan E-learning dengan Model Delone dan McClean
}

\author{
Elsi Puspita Sari \\ Program Studi Magister Teknologi \& Kejuruan, Fakultas Teknik, Universitas Negeri Padang \\ Email: elsi.puspita.s@gmail.com
}

Sukardi
Jurusan Teknik Elektro, Fakultas Teknik, Universitas Negeri Padang

Email: sukardiunp@gmail.com

Elfi Tasrif

Jurusan Teknik Elektronika, Fakultas Teknik, Universitas Negeri Padang Email: elfitasrif@ft.unp.ac.id

Ambiyar

Jurusan Teknik Mesin, Fakultas Teknik, Universitas Negeri padang, Email: ambiyar@ft.unp.ac.id

\author{
A R T I C L E I N F O \\ Article history: \\ 1 Maret 2020 Received in \\ revised form \\ 30 Maret 2020 \\ Accepted 11 April 2020 \\ Available online 15 \\ Mei 2020

\section{Kata Kunci:} \\ Sistem Informasi, E- \\ learning, Delone dan \\ Mcclean \\ Keywords: \\ Information System, E- \\ learning, Delone and \\ Mcclean
}

\begin{abstract}
A B S T R A K
Perkembangan teknologi dan informasi yang cepat telah mempengaruhi berbagai aspek kehidupan termasuk dalam bidang pendidikan, oleh karena itu, dalam penerapan perlu inovasi pendidikan dengan menerapkan e-learning di lembaga pendidikan, Universitas Negeri Padang (UNP) salah satu lembaga pendidikan yang menerapkan e-learning. Penelitian ini penelitian evaluasi dengan metode kuantitatif. Dalam peneliti mengevaluasi e-learning UNP menggunakan model kesuksesan sistem informasi DeLone \& McClean. Penelitian ini diharapkan dapat mengetahui gambaran dari e-learning UNP. Berdasarkan analisis data ditemukan bahwa data kuantitatif, kualitas sistem dilihat bahwa tingkat capaian responden (TCR) mencapai 88, 07\% tentu dikategorikan baik. Kualitas informasi dilihat bahwa TCR mencapai $87,36 \%$ juga dikategorikan baik. Kualiatas layanan dapat dilihat bahwa TCR mencapai $87,76 \%$ dikategorikan baik. Penggunaan bahwa TCR mencapai $88,24 \%$ tentu dikategorikan baik. Kepuasan pengguna bahwa TCR mencapai $88,73 \%$ tentu dikategorikan baik. Manfaat berish TCR yang mencapai $84,10 \%$ tentu juga dikategorikan baik. Jadi, e-learning UNP mempunyai hasil pengukuran "Baik" pada semua variabel pengukuran, tentunya akan mempengaruhi penggunaan pada e-learning itu sendiri, terutama pengelolaan oleh tenaga pendidik dan penggunaan oleh peserta didik.
\end{abstract}

\section{A B S T R A C T}

The University of Padang (UNP) is one of the educational institutions in implementing e-learning. This research used quantitative method. The researcher evaluated e-learning by using the information success system DeLone \& McClean model. This research was expected to be able to find out the overview of UNP e-learning. Based on data analysis, it showed that respondents' level of achievement (TCR) reached $88.07 \%$ was categorized into good. The quality of information showed that the TCR reached $87.36 \%$ was categorized into good. Service quality of TCR reached $87.76 \%$ was categorized into good. The use that TCR reached $88.24 \%$ was categorized into good. Respondents' satisfaction showed that TCR reached $88.73 \%$ was categorized into good. The benefit of TCR reached $84.10 \%$ was categorized into good. So, e-learning of Padang University had "Good" measurement on all variables, of course it would affect the use of e-learning itself, especially managed by educators and students' use.

\section{Pendahuluan}

Zaman revolusi Industri 4.0 adalah salah satu tantangan yang harus dihadapai dan dijalani oleh negaranegara yang ada di dunia, tidak ketercuali Indonesia. Dengan adanya revolusi Industri 4.0 akan menyebabkan perubahan yang besar pada segala bidang. Salah satu bidang yang terpengaruh dengan adanya revolusi Industri 4.0 adalah bidang pendidikan. Bidang pendidikan adalah salah satu bidang yang mencetak sumber daya manusai yang berkualitas serta mampu bersaing dengan sumber daya manusia yang lain yang tentunya mempunyai kemapuan 4C (critical thingking, creative, colaboratif and communication). Untuk menghasilkan sumber daya yang mempunyai kemapuan $4 \mathrm{C}$ maka lembaga-lembaga pendidikan mengembangkan metode pembelajaran yang sesaui dengan tuntuan serta sesaui dengan perkembangan zaman revolusi Industri 4.0. Lembaga pendidikan tinggi (Universitas) menghadapi perubahan besar di berbagai lingkungan mereka. Mahasiswa saat ini tumbuh dengan internet dan perangkat digital. Oleh karena itu, perilaku mereka berbeda dari generasi sebelumnya. Dengan 
demikian, tantangan praktisi pendidikan bisa mengembangkan pendidikan yang sesuai untuk pola pembelajaran, karakteristik, dan perilaku mereka. Kehadiran internet telah merubah dunia bisnis dan dunia pendidikan. Sebagai contoh mahasiswa S2 PTK FT Universitas Negeri Padang Angkatan Semester Genap 2017 yang telah menyelesaikan seluruh mata kuliahnya pada Desember 2019, hanya 7,14\% yang melaksanakan mata kuliah mengimplementasikan e-learning sebagai bagian pembelajaranya dari total keseluruhan 14 mata kuliah yang secara umum metode yang digunakan dalam perkuliahan relatif sama. Dari hasil observasi yang dilakukan serta menggunakan langsung e-learning pada mata kuliah Analisis Jaringan Komputer. Ada beberapa kelebihan dan kekurangan $e$-learning yang rasakan selama perkuliahan. Kelebihanya: 1) $e$-learning mempunyai fitur yang cukup lengkap, 2) tampilan yang digunakan cukup sederhana, dan lain sebagainya. Adapun kekurangan yang yang dirasakan yaitu: 1) kurang fleksibel digunakan pada perangkat yang berbeda terutama perangkat mobile, 2) sedikit menyulitkan bagi yang sedikit gagap dalam penggunaan teknologi, 3) masih kurang menarik dan fleksibel desain dari e-learning, dan lain sebagainya. Penerapan sebuah sistem dalam hal ini e-learning tidak terlepas dari tahap merancang, mendesain, mengembangkan serta mengevaluasi e-learning. Dengan melalui proses tersebat sebuah program akan bisa digunakan dengan baik dan nantinya akan berdampak terhadap hasil capaian mahasiswa yang menggunakannya. Masalahnya kemudian muncul yaitu bagaimana cara mengevaluasi sebuah program e-learning agar program e-learning yang dikembangkan sesaui dengan keperuntukannya. Salah satu model pengukuran kesuksesan SI yang sering digunakan adalah information system success measurement yang dikenalkan oleh DeLone dan McLean 2003. Evaluasi e-learning ini melihat kesuksesan SI ini dengan model DeLone dan McLean 2003 apakah sudah sesuai atau belum dengan model tersebut. Tujuan penelitian ini adalah untuk dapat mengetahui e-learning Universitas Negeri Padang (UNP) dengan model kesuksesan sistem informasi DeLone dan McClean 2003.

E-learning adalah salah satu metode pembelajaran baru yang memanfaatkan teknologi elektronik. Perkembangannya bukan hanya di Indonesia bahkan Negara-negara maju sudah menggunakn e-learning lebih dahulu. E-learning berasal dua kata yakni "e" dan "learning". "e" merupakan singkatan dari electronic dan learning adalah pembelajaran. Jadi E-learning dapat diartikan sebagai pembelajaran yang menggunakan media elektronik (Mutia dan Leonard, 2013). Banyak ahli yang berpendapat tentang e-learning sesuai sudut pandangnya masing-masing Khan (2015) dalam Santi (2018) menyatakan bahwa e-learning adalah pendekatan pembelajaran inovatif yang menarik, yang bersifat fleksibel, berpusat belajar terhadap siswa, interaktif, dan tentunya bisa diakses kapanpun, dimanapun dan oleh siapapun. Menurut Ruth Colvin Clark dan Richard E. Mayer mendefinisikan $e$ learning sebagai proses pembelajaran yang menggunakan komputer dengan sarana CD-ROM, internet, dengan konten yang disampaikan relevan dengan objek yang dipelajari, dengan mengunakan metode metode pembelajaran contoh atau panduan, menggunakan media tulisan dan gambar yang berfungsi sebagai pembangun pengetahuan baru serta kemampuan pada individu atau organisasi (Nunu, 2018). Sedangkan Turban dalam Suwastika (2018) menyatakan bahwa e-learning adalah sebuah program pengiriman informasi online untuk tujuan pendidikan, pelatihan, atau manajemen pengetahuan. Dari jabaran tersebut dapat dikatakn bahwa e-learning adalah sebuah proses pembelajaran yang dilakukan dengan bantuan alat elektronik yang memberikan kesempatan kepada siswa untuk belajar lebih terbuka, fleksibel serta mandiri melalui diskusi, pemberian tugas dan lain-lain. Pemanfaatan $e$ learning dalam proses pembelajaran diharapkan mampu untuk meningkatkan efektifitas dan efisiensi pendidikan. Efektif dari segi penyediaan materi oleh pendidik yang dapat diakses oleh peserta didik kapanpun dan dimanapun. Kemudian efisien dari segi pelaksanaan tugas, kuis, dan ujian harian yang dilaksanakan secara online. Peserta didik tidak lagi mengerjakan tugas, kuis, dan ujian harian dalam bentuk hardcopy tetapi dalam bentuk softcopy. Selain itu, peserta didik juga berkesempatan untuk memperoleh informasi dari mana saja dan kapan saja dalam mengikuti perkembangan ilmu pengetahuan. Mereka bisa berdiskusi dan berkonsultasi dengan para ahli di seluruh dunia sehingga wawasan dan pengetahuan yang didapat akan semakin luas dan dapat meminimalisir terjadinya peserta didik yang gagap akan teknologi.

Proses penerapan e-learning, tidak terlepas dari beberapa komponen di dalamnya, komponen-komponen yang harus dilkukan adalah: (1) konten yang relevan; (2) menggunakan metode pembelajaran, seperti diskusi, pemberian masalah; (3) menggunakan elemen media seperti kalimat dan gambar untuk mendistribusikan konten dan metode belajar; (4) pembelajaran dapat dilakukan secara langsung dengan instruktur (synchronous) ataupun belajar secara individu (asynchronous); serta (5) membangun wawasan dan teknik baru yang dihubungkan dengan tujuan belajar.(Santi, 2018). Menurut Gottschalk (1995), komponen-komponen utama dalam e-learning terdiri dari: 1) Pelajar. 2) Fakultas/ instruktur. 3) Fasilitator. 4) Staf pendukung. 5) Administrator. Sedangkan menurut Khan (2005:8-10) beberapa komponen yang harus diketahui oleh lembaga yang ingin menerapkan e-learning, yaitu (1) desain pembelajaran; (2) komponen multimedia; (3) peralatan internet; (4) komputer dan penyimpanan alat; (5) penyambungan dan layanan providers; (6) power/program manajemen, merencanakan sumber perangkat lunak, dan standar-standarnya; serta (7) layanan dan aplikasi sambungan.

Banyak penelitian yang sudah dilakukan yang berakaitan dengan dengan analysis penggunaan e-learning, menurut Nunu (2018) Pengelolaan pembelajaran online di perguruan tinggi Islam perlu ditangani secara optimal, maka pengelola harus menjalankan tugas-tugas manajerial pembelajaran berbasis online dengan baik dengan 
berpegang pada prinsip-prinsip manajerial yaitu; 1) Memprioritaskan tujuan di atas kepentingan pribadi dan kepentingan mekanisme kerja, 2) Mengkoordinasikan wewenang dan tanggung jawab, 3) Memberi tanggung jawab kepada bawahan harus sesuai dengan sifat-sifat dan kemampuannya, 4) mengenal secara baik faktor-faktor psikologi manusia, dan 5) Relativitas nilai-nilai. Menurut Santi (2018) proses pembelajaran menggunakan $e$ learning dengan blended learning sudah berjalan dengan baik karena sudah melewati tahap perencanaan, desain, pengembangan serta evaluasi. Sehingga e-learning yang diterapkan baik, akan tetapi kendala yang dihadapui adalah masih kurangnya peranan pengampu kebijakan. Pendapat dari Basrie dan Amelia (2018) adalah pada proses Perkuliahan di STMIK Widya Cipta Dharma penggunaan E-learning di kampus masih belum ada yang menggunakannya. Maka dibuatlah Sistem Informasi E-learning pada STMIK Widya Cipta Dharma Untuk membantu dalam proses belajar dan mengajar, dan dalam pengujian hasil digunakan metode Pengujian Beta agar fungsi dan kegunaannya nanti bisa dibuat sebagai pengajuan ke lembaga STMIK Widya Cipta Dharma. Menurut Wiwin (2016), keberhasilan e-learning ditunjang oleh adanya interaksi maksimal antara pendidik dan peserta didik, antara peserta didik dengan berbagai fasilitas pendidikan, antara peserta didik dengan pengan peserta didik lainnya, dan adanya pola pembelajaran aktif dalam interaksi tersebut. Sedangkan menurut Haryoso (2018) diperlukan suatu kebijakan, perencanaan, implementasi serta evaluasi yang tepat \& konsisten untuk menjaga kualitas pembelajaran Blended Learning. Di artikel ini dituliskan tentang bagaimana kebijakan, perencanaan, implementasi \& evaluasi pelaksanaan pembelajaran materi kuliah berbasis Blended Learning di STMIK Indonesia Mandiri \& STIE-STAN Indonesia Mandiri Bandung. Dari penelitian-penelitian tersebut dapat dikatakan bahwa e-learning akan berjalan dengan baik apabila adanya rancangan, desain, pengembangan dan evaluasi yang jelas, serta kontribusi dari beberapa aspek atau komponen yang diantaranya adalah mahasiswa, dosen, tim IT dan staf adminstratif. Salah satu aspek yang penting dalam e-learning adalah sistem evaluasi apakah e-learning sudah dapat digunakan secara optimal atau belum.

Evaluasi merupakan penentuan hasil nilai suatu hal, yang dapat meliputi informasi yang digunakan untuk memutuskan nilai keberhasilan suatu program, produk, prosedur, tujuan atau manfaat yang pada desain pendekatan alternativ untuk mempertahankan tujuan khususnya. Evaluasi merupakan suatu proses yang dapat menyediakan informasi yang dijadikan sebagai bahan pertimbangan untuk menentukan hasil nilai dan harga dari tujuan yang dicapai, desain, implementasi dan sebagi rekomendasi dalam membuat keputusan, membantu mempertanggung jawabkan dan meningkatkan pemahaman terhadap fenomena. Sehingga evaluasi dapat berarti penyediaan informasi yang dapat disajikan sebagai bahan pertimbangan dalam mengambil sebuah keputusan. Suharsimi (2008:2) berpendapat bahwa evaluasi merupakan kegiatan untuk mengumpulkan informasi tentang bekerjanya sesuatu, yang selanjutnya informasi tersebut digunakan untuk menentukan alternatif yang tepat dalam mengambil sebuah keputusan. Evaluasi adalah suatu alat atau prosedur yang digunakan untuk mengetahui dan mengukur sesuatu dalam suasana dengan cara dan aturan-aturan yang sudah ditentukan (Muryadi, 2017:3). Seperti jabaran sebelumnya bahwa e-learning juga harus di evaluasi, banyak cara yang bisa dilakukan salah satu cara evaluasinya yaitu information system success measurement yang dikenalkan oleh DeLone dan McLean 2003 (Model DeLone and McLean 2003).

Model kesuksesan DeLone dan McLean yaitu sebuah model yang sederhana, lengkap dan valid dalam mengukur kesuksesan (Garrity \& Sanders, 1998 dalam Lely, dkk. 2018) Model DeLone and McLean yaitu model yang mempunyai 6 variabel evaluasi yaitu: information quality, system quality, service quality, use, user satisfaction dan net benefit (Pujo Hari Saputro, A. Djoko Budiyanto, Alb. Joko Santoso, 2015). DeLone dan McLean melakukan penelitian yang bertujuan untuk mengetahui aspek-aspek yang akan mempengaruhi kesuksesan SI, model kesuksesan SI memiliki tiga komponen yaitu sebagai berikut: pembuatan sistem, penggunaan sistem, dan dampak dari penggunaan sistem. Pembuatan sistem dinilai dengan kualitas sistem, kualitas informasi dan kualitas pelayanan (service quality). Penggunaan sistem dinilai dengan variabel penggunaan (use) dan kepuasan pengguna (user satisfaction) dan dampak dari penggunaan sistem dinilai dari manfaat bersih (net benefit) yang diperoleh. Model DeLone and McLean 2003 menggunakan enam pengukuran kesuksesan SI keenam komponen maupun pengukuran dari model kesuksesan ini adalah kualitas sistem (system quality), kualitas informasi (information quality), kualitas layanan (service quality), penggunaan (use), kepuasan pemakai (user satisfaction), dan manfaat bersih (net benefit) (DeLone dan McLean, 2016:8). Model Kesuksesan Sistem Informasi DeLone dan McLean adalah model yang cocok untuk mengukur keberhasilan dari penerapan sistem informasi pada sebuah organisasi atau perusahaan (Jamal dan Dwiza, 2016).

Beberapa penelitian menggunakan Model kesuksesan DeLone dan McLean dilakukan, antara lain penelitian Lely, dkk. (2018) menyatakan bahwa Penerapan model DeLone dan McLean menunjukkan bahwa tingkat kesuksesan pada website FILKOM adalah cukup atau sedang. Penggunaan analisis product moment Pearson membenarkan hipotesis penelitian yaitu setiap variabel memiliki hubungan yang positif dan signifikan pada variabel lain yang terhubung sesuai model DeLone dan McLean. Pendapat Pujo Hari Saputro, A. Djoko Budiyanto, Alb. Joko Santoso (2015) adalah metode DeLone and McLean yaitu metode yang mempunyai 6 variabel evaluasi yaitu: information quality, system quality, service quality, use, user satisfaction dan net benefit. Metode DeLone and McLean akan digunakan sebagai model mengukur kesuksesan Egovernment dalam 
penggunaannya untuk membantu kinerja pegawai pemerintahan kota pekalongan. Dengan model ini diharapkan dapat diketahui komponen-komponen yang mendukung atau menghambat dalam penggunaan E-government, sehingga ke depan diharapkan dapat menjadi bahan evaluasi untuk perbaikan. Berdasarkan paparan tersebut, model DeLone dan McLean efektif digunakan dalam negevalusi sebauh program seperti e-learning ataupun program jenis lainnya.

\section{Metode}

Penelitian ini adalah penelitian evaluasi dengan metode deskriptif. Dalam hal ini peneliti mengevaluasi $e$ learning UNP menggunakan model kesuksesan sistem informasi DeLone \& McClean 2003 dengan indikator berupa kualitas sistem (system quality), kualitas informasi (information quality), kualitas layanan (service quality), and penggunaan (use), kepuasan pemakai (user satisfaction) dan manfaat bersih (net benefit). Penelitian ini diharapkan dapat mengetahui gambaran dari e-learning UNP. Metode penelitian yang digunakan dalam penelitian ini metode Kuantitatif karena dalam metode yang digunakan ini untuk menghasilkan data penelitian berupa angkaangka dan analisis menggunakan statistik (Sugiyono, 2015:13). Lokasi penelitian di S2 PTK UNP yang akan dilaksanakan pada mata kuliah Analisis Jaringan Komputer. Jadwal penelitian dilaksanakan pada bulan Februari 2020. Dalam prosedur penelitian ini bahwa penelitian ini menggunakan metode kuantitatif. Instrumen yang digunakan dalam metode kuantitatif adalah kuesioner (angket). Angket diberikan kepada mahasiswa. Setelah penyebaran instrumen dilakukan kemudian melakukan analisis terhadap data yang telah diperoleh untuk mengetahui tingkat pencapaian responden pada masing-masing indikator. Hasil analisis data kuantitatif ini dilakukan untuk pengambilan kesimpulan dan rekomendasi dari masing-masing indikator. Responden atau sumber data dalam penelitian ini adalah orang-orang yang terlibat dalam pembelajaran e-learning pada mata kuliah Analisis Jaringan Komputer di S2 PTK UNP. Responden atau sumber data dalam penelitian ini adalah orang-orang yang terlibat dalam pembelajaran e-learning pada mata kuliah Analisis Jaringan Komputer di S2 PTK UNP (Kelas A), dengan jumlah mahasiswa 16 orang, selanjutnya akan digunakan teknik Nonprobalibility Sampling dengan pengambilan sampelnya menggunakan sampling jenuh. Sampling jenuh adalah teknik penentuan sampel bila semua anggota populasi digunakan sebagai sampel penelitian (Ambiyar, 2015:180).

Teknik pengumpulan data ini dengan kuantitatif, yang digunakan pada penenelitian ini yaitu kuesioner (angket). Jenis angket yang dihunakan adalah angket tertutup, dimana komunikasi dilakukan dengan cara tidak langsung. Responden diminta untuk memilih satu jawaban yang sesuai dengan karakteristik dirinya dengan cara memberikan tanda silang (x) atau tanda checklist $(\sqrt{ })$. Kuesioner disusun berdasarkan model kesuksesan Sistem Informasi DeLone dan McClean yaitu kualitas sistem (system quality), kualitas informasi (information quality), kualitas layanan (service quality), penggunaan (use), kepuasan pengguna (user satisfaction) dan manfaat bersih (net benefit) dengan menggunakan skala Likert yaitu dengan lima alternatif jawaban. Jawaban tersebut mempunyai skor minimal dan maksimal. Seperti yang terlihat pada tabel 1 di bawah ini.

Tabel 1. Skor Item Pernyataan

\begin{tabular}{lcc}
\hline Item Pernyataan & Positif & Negatif \\
\hline Sangat Baik (SB) & 5 & 1 \\
Baik (B) & 4 & 2 \\
Cukup (C) & 3 & 3 \\
Kurang Baik (KB) & 2 & 4 \\
Sangat Kurang Baik (SKB) & 1 & 5 \\
\hline
\end{tabular}

Penyususnan instrumen dilakukan dengan langkah-langkah sebagai berikut: 1) Membuat kisi-kisi instrumen penelitian berdasarkan indikator dari masing-masing tahapan evaluasi yang digunakan yaitu model kesuksesan sistem informasi DeLone dan McClean, 2) Menyusun butir-butir pernyataan sesuai dengan indikator, dan 3) Melakukan uji coba instrumen untuk mendapatkan instrumen yang valid dan reliabel.

Tabel 2. Kisi-kisi Uji Coba Instrumen Penelitian.

\begin{tabular}{lll}
\hline $\begin{array}{l}\text { Komponen Evaluasi model } \\
\text { DeLone dan McClean } \\
\text { (Indikator) }\end{array}$ & Butir Instrument & $\begin{array}{l}\text { Teknik Pengumpulan } \\
\text { data }\end{array}$ \\
\hline & Kemudahan untuk digunakan & $\mathrm{A}$ \\
Kualitas Sistem & Kehandalan sistem & $\mathrm{A}$ \\
& Kecepatan akses & $\mathrm{A}$ \\
& Fleksibilitas sistem & $\mathrm{A}$ \\
\hline Kualitas Informasi & Keamanan sistem & $\mathrm{A}$ \\
\hline
\end{tabular}




\begin{tabular}{lll} 
& Relevan & A \\
& Akurat & A \\
& Ketepatan waktu & A \\
\hline \multirow{2}{*}{ Kualitas Pelayanan } & Jaminan & A \\
& Empati & A \\
\hline Penggunaan & Sifat penggunaan & A \\
\hline \multirow{2}{*}{ Kepuasan Pengguna } & Kepuasan informasi & A \\
& Kepuasan menyeluruh & A \\
\hline Manfaat Bersih & Meningkatkan berbagi pengetahuan & A \\
& Efektivitas komunikasi & A \\
\hline
\end{tabular}

Instrumen penelitian ini diujicobakan pada responden yang bukan merupakan sampel penelitian. Dalam penelitian ini angket diujicobakan kepada mahasiswa S2 PTK UNP Kelas B (mata kuliah Analisis Jaringan Komputer) dengan jumlah siswa 10 orang. Pemilihan responden ini didasarkan karena memiliki karakteristik yang sama yaitu sama-sama mahasiswa S2 PTK UNP dan menggunakan e-learning. Setelah dilakukan uji coba instrumen maka dilakukan uji validitas dan uji reliabilitas instrumen. Pengujian validitas ini dilakukan untuk melihat ketepatan instrumen dengan apa yang ingin diukur. Selain itu, uji reliabilitas ini dilakukan untuk melihat kehandalan instrumen yang telah disusun.

Analisis data kuantitatif ini dilakukan dengan beberapa tahapan sebagai berikut ini: 1) Melakukan dengan tabulasi data terhadap angket yang telah diisi oleh responden. 2) Melakukan perhitungan setiap skor indikator yang telah ditentukan. 3) Menghitung skor total. 4) Melakukan analisis deskriptif. Statistik yang digunakan dalam penelitian ini adalah statistik deskriptif, yaitu statistik yang digunakan untuk menganalisis data dengan cara mendeskripsikan atau menggambarkan data yang telah terkumpul dengan penyajian data melalui tabel, grafik, diagram lingkaran, perhitungan modus, median, mean, perhitungan desil, persentil, perhitungan penyebaran data melalui perhitungan rata-rata dan standar deviasi serta perhitungan persentase. 5) Menganalisis dengan analisis persen. Dalam Riduwan (2009:102) untuk mengetahui tingkat pencapaian responden digunakan rumus sebagai berikut ini:

$$
\text { Tingkat Pencapaian Responden }=\frac{\text { skor rata }- \text { rata }}{\text { skor ideal maksimum }} \times 100 \%
$$

Pengkategorian tingkat pencapaian responden digunakan klasifikasi yang dikemukakan Sudjana (2009:29), seperti pada tabel di bawah ini.

Tabel 4. Rentang Kategori Tingkat Pencapaian Responden

\begin{tabular}{ll}
\hline Rentang Persentase & Kategori \\
\hline $90 \%-100 \%$ & Sangat Baik \\
$80 \%-89 \%$ & Baik \\
$65 \%-79 \%$ & Cukup \\
$55 \%-65 \%$ & Kurang \\
$0 \%-54 \%$ & Kurang Sekali \\
\hline
\end{tabular}

\section{Hasil dan Pembahasan}

Penelitian dilaksanakan pada bulan Februari 2020. Sampel dalam penelitian adalah mahasiswa S2 PTK FT UNP kelas Analisis Jaringan Komputer. Jumlah sampel sebanyak 16 mahasiswa dan untuk uji responden sebanyak 10 mahasiswa. Data dalam penelitian ini diambil dengan menggunakan angket yang berisikan pertanyaanpertanyaan mengenai e-learning Universitas Negeri Padang (UNP). Pengolahan data hasil penelitian diolah menggunakan Ms.Excel dan SPSS v25, maka didapatkan hasil sebagai berikut: Menyusun kisi-kisi untuk pendekatan kuantitatif (kisi-kisi angket) berdasarkan model DeLone dan McLean.Uji coba angket kepada mahasiswa S2 PTK FT yang mempunyai kriteria yang sama dengan sampel penelitian. Uji coba dilakukan kepada kelas Analisis Jaringan Komputer (TIK B) yang berjumlah 10 orang. Analisis validitas yang dilakukan pada butir angket yang berjumlah 41 butir, diperoleh hasil sebagai berikut: komponen kualitas sistem, kualitas informasi, pengguna, kepusaan pengguna dan manfaat bersih semua no item dinyatakan valid ada 1 komponen kualitas layanan butir instrument empati terdiri dari 3 item pertanyaan terdapat 1 item yang tidak valid yaitu item nomor 25.

Sesuai pejabaran pada metode sebelumnya ada beberapa variable yang dinilai dalam penelitian yang sesaui dengan model DeLone dan McClean adalah: 


\section{Kualitas Sistem}

Hasil penelitian dengan indikator kualitas sistem yang terdiri dari 11 pertanyaan. Berikut analisis data dari kualitas sistem. Berdasarkan data hasil pengolahan kuisioner yang disebarkan kepada 16 mahasiswa yang kuliah Analisis Jaringan Komputer memiliki persentase sebesar 44,32\% mengatakan sangat baik, 39,20\% mengatakan baik, yang mengatakan cukup 6,82\% untuk yang mengatakan kurang baik $0,57 \%$, dan yang mengatakan sangat kurang baik yang nilainya $0 \%$. Indikator kualitas sistem diperoleh skor rata-rata 4,40. Skor ideal maksimum adalah 5 dan tingkat capaian responden adalah $88,07 \%$ dengan kategori penilaian baik. Dengan demikian dapat diartikan bahwa indikator kualitas sistem berdasarkan data hasil sudah baik.

\section{Kualitas Informasi}

Hasil penelitian dengan indikator kualitas informasi yang terdiri dari 9 pertanyaan. Berikut analisis data dari kualitas informasi. Berdasarkan data hasil pengolahan kuisioner yang disebarkan kepada 16 mahasiswa yang kuliah Analisis Jaringan Komputer memiliki persentase sebesar 47,22\% mengatakan sangat baik, 43,75\% mengatakan baik, yang mengatakan cukup 7,64\% untuk yang mengatakan kurang baik 1,39\%, dan yang mengatakan sangat kurang baik nilainya $0 \%$. Indikator kualitas informasi diperoleh skor rata-rata 4, 37 . Skor ideal maksimum adalah 5 dan tingkat capaian responden adalah 87, 36\% dengan kategori penilaian baik. Dengan demikian dapat diartikan bahwa indikator kualitas informasi berdasarkan data hasil sudah baik.

\section{Kualitas Layanan}

Hasil penelitian dengan indikator kualitas layanan yang terdiri dari 5 pertanyaan. Berikut analisis data dari kualitas layanan. Berdasarkan data hasil pengolahan kuisioner yang disebarkan kepada 16 mahasiswa yang kuliah Analisis Jaringan Komputer memiliki persentase sebesar 46,25\% mengatakan sangat baik, 46,25\% mengatakan baik, yang mengatakan cukup 7,50\% untuk yang mengatakan kurang baik dan sangat kurang baik nilainya $0 \%$. Indikator kualitas layanan diperoleh skor rata-rata 4, 39. Skor ideal maksimum adalah 5 dan tingkat capaian responden adalah 87, 76\% dengan kategori penilaian baik. Dengan demikian dapat diartikan bahwa indikator kualitas layanan berdasarkan data hasil sudah baik.

\section{Pengguna}

Hasil penelitian dengan indikator pengguna yang terdiri dari 5 pertanyaan. Berikut analisis data dari pengguna. Berdasarkan data hasil pengolahan kuisioner yang disebarkan kepada 16 mahasiswa yang kuliah Analisis Jaringan Komputer memiliki persentase sebesar 51,25\% mengatakan sangat baik, 40,00\% mengatakan baik, yang mengatakan cukup 7,50\% untuk yang mengatakan kurang baik 1,25\%, dan yang mengatakan sangat kurang baik nilainya 0\%. Indikator pengguna diperoleh skor rata-rata 4,41. Skor ideal maksimum adalah 5 dan tingkat capaian responden adalah $88,24 \%$ dengan kategori penilaian baik. Dengan demikian dapat diartikan bahwa indikator pengguna berdasarkan data hasil sudah baik.

\section{Kepuasan Pengguna}

Hasil penelitian dengan indikator kepuasaan pengguna yang terdiri dari 6 pertanyaan. Berikut analisis data dari kepuasaan pengguna. Berdasarkan data hasil pengolahan kuisioner yang disebarkan kepada 16 mahasiswa yang kuliah Analisis Jaringan Komputer memiliki persentase sebesar 51,04\% mengatakan sangat baik, 41,67\% mengatakan baik, yang mengatakan cukup 7,29\% untuk yang mengatakan kurang baik dan sangat kurang baik nilainya $0 \%$. Indikator kepuasaan pengguna diperoleh skor rata-rata 4,44. Skor ideal maksimum adalah 5 dan tingkat capaian responden adalah 88,73\% dengan kategori penilaian baik. Dengan demikian dapat diartikan bahwa indikator kepuasaan pengguna berdasarkan data hasil sudah baik.

\section{Manfaat Bersih}

Hasil penelitian dengan indikator manfaat bersih yang terdiri dari 4 pertanyaan. Berikut analisis data dari manfaat bersih. Berdasarkan data hasil pengolahan kuisioner yang disebarkan kepada 16 mahasiswa yang kuliah Analisis Jaringan Komputer memiliki persentase sebesar 35,94\% mengatakan sangat baik, 51,56\% mengatakan baik, yang mengatakan cukup 9,38\% untuk yang mengatakan kurang baik 1,56\%, dan yang mengatakan sangat kurang baik nilainya $0 \%$. Indikator manfaat bersih diperoleh skor rata-rata 4, 21. Skor ideal maksimum adalah 5 dan tingkat capaian responden adalah 84, 10\% dengan kategori penilaian baik. Dengan demikian dapat diartikan bahwa indikator manfaat bersih berdasarkan data hasil sudah baik. Secara sederhana hasil penelitian ini dapat di lihat dari gambar hstrogram dibawah ini. 


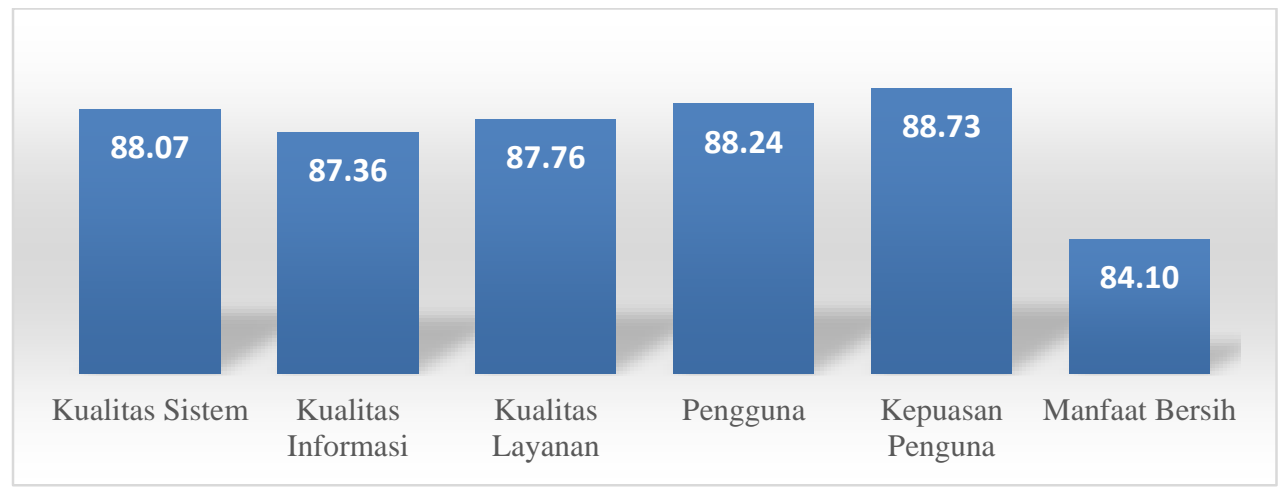

Gambar 01

Tingkat Capaian Responden E-learning UNP Berdasarkan Model DeLone \& McLean

Dari hasil penelitian yang telah dijabarkan pada deskriptif variabel, maka ditinjau dari model kesuksesan sistem informasi model DeLone \& McLean yang menggunakan indikator kualitas sistem, kualitas informasi, kualitas layanan, penggunaan, kepuasan pengguna, dan manfaat bersih akan dibahas e-learning UNP sesuai dengan masing-masing indikator tersebut. Walaupun sampel penelitian hanya 16 orang, tetapi sampel penelitian yang merupakan mahasiswa tingkat magister tentu pemahaman dan keseriusan dalam melakukan penilaian melalui kuisioner yang disusun berdasarkan indikator kesuksesan sistem informasi model DeLone \& McLean bisa dipertanggungjawabkan.

\section{Kualitas Sistem}

Seperti yang telah dijelaskan pada kajian teori, yang dimaksud dengan kualitas sistem pada model kesuksesan sistem informasi DeLone \& McLean yaitu karekteristik yang dingiinkan pada sistem informasi telah diuraikan sub-indikator yang menjadi instrument dalam pengukuran dari kualitas sistem. Karakteristik yang diinginkan dari sebuah sistem informasi, menurut Petter et all., 2008 adalah mudah digunakan, feksibel, keandalan sistem, dan kemudahan mempelajarinya serta fitur yang intuitif, kecanggihan, feksibelitas, dan waktu respon. Dengan memenuhi ciri-ciri tersebut sebauh sistem bisa dikatakan berdampak positif. Dari hasil penelitian yang dilakukan bahwa kualitas sistem menunjukkan presentase yang baik, salah satu alasanya adalah dengan adanya kualitas sistem yang baik akan membuat sistem nyaman digunakan tentunya hal ini berdampak pada kepuasan penguna. Hal ini senada dengan pendapat Noviyanti 2016 menyatakan bahwa pengaruh kualitas sistem sangat besar terhadap penggunaan sistem. Jadi dengan kualitas sistem yang baik maka pengguna akan merasa nyaman dalam penggunaan e-learning.

\section{Kualitas Informasi}

Kualitas informasi pada model kesuksesan sistem informasi DeLone \& McLean yaitu karekteristik yang dingiinkan pada sistem informasi, juga telah diuraikan sub-indikator yang menjadi instrument dalam pengukuran dari kualitas informasi. Kualitas informasi adalah karakteristik yang diinginkan dari output sistem informasi yaitu, relevan, dapat dimengerti, akurasi, keringkasan, kelengkapan, ketepatan waktu, dan kemanfaatan (Petter et al., 2008). dengan adanya kualitas informasi yang baik maka akan mepermudah pengguna dalam mendapatkan informasi akan lebih, mudah serta memeplajari dan memahamipun lebih mudah. Dengan begitu e-learning yang dikembangkan akan memeberikan kepuasan pada pengguna. Hal ini sedada dengan pendapat yang disampaikan oleh Noviyanti ( 2016). Dari hasil penelitan yang dilkukakkan menunjukkan bahwa kualitas informasi berdampak positif terhadap kepuasan pengguna. Jadi dapat dikatakan bahwa dengan Kualitas informasi yang baik maka akan menghasilkan sebuah kepuasan pengguna yang berdapak dengan penggunaan $e$-learning.

\section{Kualitas layanan}

Kualitas layanan pada model kesuksesan sistem informasi DeLone \& McLean yang merupakan sebuah perbandingan dari harapan pelanggan dengan persepsi dari layanan nyata yang mereka terima, telah diuraikan subindikator yang menjadi instrument dalam pengukuran dari kualitas layanan. Petter et al. (2008) menyatakan bahwa kualitas layanan adalah kualitas dari system support dari departemen sistem informasi dan petugas teknologi informasi. Kualitas layanan dpat diukur pada layanan akhir dari proses produksi, penyuplai pengolahan data, dan pada hubungan layanan akhir yaitu antara staf yang melayani dan pengguna sistem (Ding, 2010). Kualitas layanan adalah hal yang tidak bisadilepaskan dari sebuah system, layanan bisa diberikan kepada pengguna yang menggunakan e-learning. Layanan yang berkualitas akan membuat pengguna merasa nyaman mengunakan $e$ - 
learning. Dengan nyaman menggunakan e-learning maka pengguna akan lebih tertarik dalam menggunakannya serta tentunya itu akan berdampak terhadap psikologis pengguna.

\section{Kepuasan Pengguna}

Penggunaan adalah tingkatan dan cara dimana pengguna memanfaatkan kemampuan dari suatu sistem informasi, telah diuraikan sub-indikator yang menjadi instrument dalam pengukuran dari penggunaan. Penggunaan sistem adalah tingkat penggunaan sistem oleh staff baik frekuensi, sifat penggunaan, kelayakan penggunan, tujuan penggunaan dan manfaat tambahan dari pemanfaatan sistem. (Petter et al., 2008). Adanya sifat penggunaan maka intensitas penggunaan tidak dapat dijadikan indikator keberhasilan sistem, namun penggunaan aktual yang dijadikan dimensi untuk mengukur kebarhasilan sistem informasi. (Wahyuni (2011), Efendy (2013), Purwanto (2007) dalam Noviyanti 2016).

\section{Manfaat Bersih}

Manfaat bersih seperti yang telah dijelaskan pada kajian teori, yang dimaksud dengan manfaat bersih pada model kesuksesan sistem informasi DeLone \& McLean yaitu hasil dari penggunaan sistem informasi yang memberikan kontribusi bagi individu, kelompok, dan organisasi atau manfaat bersih, yang telah diuraikan subindikator yang menjadi instrument dalam pengukuran dari manfaat bersih. Menurut DeLone dan McLean, keuntungan bersih merupakan variabel yang paling penting dalam mengukur kesuksesan suatu sistem informasi. (DeLone \& McLean, 2003). Manfaat bersih menggambarkan persepsi yang berbeda dari stakeholder, organisasi atau individu. Manfaat bersih adalah penilaian komprehensif dari masa lalu dan harapan pada masa depan atas implementasi teknologi informasi (Seddon, 1997 dalam Noviyati, 2016). Pengaruh positif manfaat bersih terhadap kepuasan pengguna dengan nilai 10.20 dimana nilai tersebut lebih besar dari 1,963 dapat diartikan bahwa semakin tinggi manfaat bersih yang didapatkan, maka hal itu akan diikuti oleh peningkatan kepuasan pengguna, demikian juga sebaliknya, (Andrawati, 2016).

Dalam model kesuksesan sistem informasi model DeLone \& McLean antar masing-masing dimensi pengukur tidak bersifat independent, tetapi mempunyai hubungan kausal. Dalam hubungan kausal tentunya antara variabel satu dengan yang lainnya mempunyai hubungan sebab akibat, sehingga hubungan antar masing-masing variabel merupakan satu kesatuan yang saling mempengaruhi. Jadi dalam mengevaluasi kesuksesan sebuah sistem informasi, model kesuksesan sistem informasi yang dikembangkan oleh DeLone \& McLean apabila salah satu dari variabel yang menjadi dimensi pengukuran mempunyai hasil pengukuran yang berbeda dari variabel lainnya, tentunya akan mempengaruhi sistem informasi secara keseluruhan atau ada sesuatu yang kurang tepat dalam mendesain sistem informasi tersebut. Dalam hal ini elearning UNP mempunyai hasil pengukuran "Baik", dengan nilai TCR yang tidak terlalu signifikan perbedaanya. Jadi tentunya hasil pengukuran ini bisa dijadikan pedoman untuk mengeluarkan rekomendasi terhadap e-learning UNP.

\section{Simpulan dan Saran}

Berdasarkan hasil penelitian evaluasi e-learning yang dilaksanakan di Universitas Negeri Padang, maka dapat ditarik kesimpulan dari penelitian yaitu bahwa elearning UNP dikategorikan baik. Berdasarkan model kesuksesan sistem informasi DeLone \& McClean bisa dilihat bahwa masing-masing variabel yang menjadi instrument pengukuran mempunyai hasil pengukuran yang baik juga, karena apabila salah satu variabel mempunyai perbedaan hasil pengukuran yang signifikan tentunya menjadikan sistem informasi tidak sukses secara keseluruhan karena antar variabel mempunyai hubungan kausal. Kategori baik yang didapat oleh e-learning UNP bisa dijadikan pedoman untuk pengembangan e-learning UNP kedepannya agar lebih optimal dan bisa mencapai kategori sangat baik. Dari hasil penelitian yang menyatakan elearning UNP pada kategori baik tentunya akan mempengaruhi penggunaan pada e-learning itu sendiri, terutama pengelolaan oleh tenaga pendidik dan penggunaan oleh peserta didik. Dari hasil penelitian maka bisa dikemukakan rekomendasi yaitu e-learning UNP tetap dilanjutkan tetapi dengan beberapa revisi, hal ini dikarenakan ada beberapa kelemahan yang bisa dilihat pada TCR masing-masing item yang belum mencapai hasil seperti yang diharapkan.

\section{Daftar Pustaka}

Ambiyar dan Syahril (2015) Statistik. Padang: Universitas Negeri Padang

Andarwati, Mardiana.2016. Analisis Faktor Yang Mempengaruhi Kesuksesan Penggunaan Core Banking System (CBS) Dengan Menggunakan Model Delone dan Mclean. Jurnal Keuangan dan Perbankan, Vol.20, No.3 September 2016, hlm. 458-467 Terakreditasi SK. No. 040/P/2014 http://jurnal.unmer.ac.id/index.php/jkdp

Basrie dan Amelia Yusnita.2018. Sistem Informasi E-Learning Sebagai Sistem Perkuliahan Perguruan Tinggi (Studi Kasus: Stmik Widya Cipta Dharma Samarinda). Seminar Nasional Teknologi Informasi dan 
Komunikasi 2018 (SENTIKA 2018) ISSN: 2089-9815 Yogyakarta, 23-24 Maret 2018. https://fti.uajy.ac.id/sentika/publikasi/makalah/2018/37.pdf

DeLone, W. H. dan McLean, E. R. (2016) Information Systems Success Measurement. American University, USA. Doi: $10.1561 / 2900000005$.

Ding, Y. (2010). Quality in IS research. Theory and validation of constructs for service, information, and system.

Gottschalk, H. T. 1995. Distance Education: An Overview. Available: http://www.uidaho.edu/evo/dist1.html.

Hartanto, Wiwin. 2016. Penggunaan E-Learning Sebagai Media Pembelajaran. http://jurnal.unej.ac.id/index.php/JPE/article/download/3438/2696.

Hapsari, Lely, Trihandayani, Ismiarta Aknuranda, Yusi Tyroni Mursityo. 2018. Penerapan Model Kesuksesan Delone dan Mclean pada Website Fakultas Ilmu Komputer (FILKOM) Universitas Brawijaya. Jurnal Pengembangan Teknologi Informasi dan Ilmu Komputer e-ISSN: 2548-964X Vol. 2, No. 12, Desember 2018, hlm. 7074-7082 http://j-ptiik.ub.ac.id

Hari, Pujo, Saputro, A. Djoko Budiyanto, dan Alb. Joko Santoso. 2015. Model Delone and Mclean untuk Mengukur Kesuksesan E-government Kota Pekalongan. Scientific Journal of Informatics Vol. 2, No. 1, Mei 2015 p-ISSN 2407-7658 http://journal.unnes.ac.id/nju/index.php/sji e-ISSN 2460-0040.

Jamal Maulana Hudin dan Dwiza Riana. 2016. Kajian Keberhasilan Penggunaan Sistem Informasi Accurate dengan Menggunakan Model Kesuksesan Sistem Informasi Delon dan Mclean. Jurnal Sistem Informasi (Journal of Information Systems). 1/12 (2016), 1-8 DOI: http://dx.doi.org/10.21609/jsi.v12i1.444.

Khan, B. (2005). Managing e-learning strategies: Design, delivery, implementation, and evaluation. USA: Idea Group, Inc.

Kayun, Wayan Suwastika.2018. Pengaruh E-Learning Sebagai Salah Satu Media Pembelajaran Berbasis Teknologi Informasi Terhadap Motivasi Belajar Mahasiswa. Jurnal Sistem dan Informatika Vol. 13, No. 1, November 2018. P-ISSN: 1858-473X | e-ISSN: 2460-3732. https://jsi.stikombali.ac.id/index.php/jsi/article/view/185.

Muryadi, A. D. (2017) 'Model Evaluasi Program Dalam Penelitian Evaluasi', Jurnal Ilmiah PENJAS, 3(1), p. ISSN : 2442-3874.

Maudiarti, Santi. 2018. Penerapan E-Learning di Perguruan Tinggi. PERSPEKTIF Ilmu Pendidikan - Vol. 32 No. 1 April 2018. $\quad$ DOI: $\quad$ https://doi.org/10.21009/PIP.321.7. https://media.neliti.com/media/publications/259453-penerapan-e-learning-di-perguruan-tinggi056c86ea.pdf.

Mutia, Intan dan Leonard. 2013. Kajian Penerapan E-Learning dalam Proses Pembelajaran di Perguruan Tinggi. Faktor Exacta 6(4): 278-289, 2013 ISSN: 1979-276X M.

Noviyant.2016. Mengukur Kesuksesan Sistem Akuntansi Instansi Basis Akrual (Saiba) Menggunakan Model Delone \& Mclean. Jurnal Tata Kelola \& Akuntabilitas Keuangan Negara. Volume 2, Nomor 2, Desember 2016: $151-173$

Nunu, Mahnun. 2018. Implementasi Pembelajaran Online dan Optimalisasi Pengelolaan Pembelajaran Berbasis Online di Perguruan Tinggi Islam dalam Mewujudkan World Class University. IJIEM: Kajian Teori dan Hasil Penelitian Pendidikan, Vol. 1, No. 1, April 2018. http://ejournal.uinsuska.ac.id/index.php/IJIEM/article/download/5240/3088.

Petter, S., Delone, W., \& Mclean, E. (2008). Measuring information systems success. Models, dimensions, measures, and interrelationships. European Journal of Information Systems, 17(3), 236-263.

Riduwan (2009) Dasar-dasar Statistika. Bandung: Alfabeta

Sugiyono (2015) Metode Penelitian dan Pengembangan (R\&D). Bandung: Alfabeta.

Suharsimi, A. dan Jabar, C. S. A. (2008) Evaluasi Program Pendidikan. Jakarta: Bumi Aksara.

Wicaksono, Haryoso.2018. Implementasi Blended Learning (Studi Kasus di STMIK Indonesia Mandiri \& STIESTAN Indonesia Mandiri Bandung). Jurnal Informasi Volume X No.1 / Februari / 2018. http://informasi.stmik-im.ac.id/wp-content/uploads/2018/07/03-HARYOSO-W.pdf. 